\title{
SMART GROWTH AND THE CHALLENGE OF NIMBY: MULTIFAMILY DWELLINGS AND THEIR ASSOCIATION WITH SINGLE-FAMILY HOUSE SELLING PRICES IN TALLAHASSEE, FLORIDA, USA
}

\author{
Huston GIBSON ${ }^{1)}$ Mathew BECKER ${ }^{2)}$ \\ 1) Kansas State University, U.S.A.; ${ }^{2)}$ Sentinel Real Estate Corporation, U.S.A.
}

\begin{abstract}
Citizens protest development when they consider it undesirable. One type of development commonly perceived as undesirable by single-family home owners is proximate multifamily housing, often considered a cause of property devaluation. This study assesses multifamily housing, by typology, and its monetary association with proximate single-family housing prices. The research design is a cross-sectional study using multivariate regression. The unit of analysis is the detached single-family dwelling. The study population is a sample taken from all arms-length owner-occupied, primary residence, detached single-family property transactions recorded in Tallahassee-Leon County, Florida, USA, during 2008. The key findings show no statistically significant negative associations between multifamily housing and single-family property selling prices in the sample; in fact, the two were positively correlated. These findings address singlefamily homeowner concerns about proximate multifamily housing and should bolster the political feasibility of Smart Growth policy, which recommends denser urban infill
\end{abstract}

Key Words: housing, land use, smart growth, neighborhood perception .

\section{Introduction}

Homeownership is the single largest financial investment most people will make during their lifetime (United States Department of Housing and Urban Development 1995). Furthermore, housing choice can have implications for quality of life, so housing consumers make purchasing decisions based on many factors, including affordability, location, specific housing or property attributes, and/or the characteristics of the surrounding neighborhood (Tiebout 1956, Fischel 2000). Because external neighborhood qualities are part of the decision to buy a house, it can also influence the monetary value of housing. Thus, neighborhood activities are important to many homeowners. Accordingly, NIMBY ("not in my backyard") activism is frequent amongst homeowners. NIMBY citizens will participate in local government to protest development in their neighborhoods when they consider the development undesirable. One potential type of neighborhood development often perceived as undesirable by single-family homeowners in the United States (US) is multifamily housing. US single-family homeowners will regularly protest proposed multifamily construction when it is close to their house because they fear property devaluation (Pendall 1999). However, no substantial empirical evidence shows higher density developments causes any real reduction to surrounding single-family property values. In fact, the opposite may be true.

In 1997, the United States National Association of Home Builders (NAHB), using US Census and American Housing Survey data, found that the average value of a single-family house in 
the US within 91.44 meters (300 feet) of multifamily residences increased in value at a slightly higher rate than single-family houses without multifamily residences nearby, at $2.9 \%$ versus $2.7 \%$ per year (Haughey 2005, United States National Association of Home Builders 2004). Granted, a concerned single-family homeowner might be a bit skeptical of this statistic, not just because of the source, but because the statistic is based on a national dataset. To illustrate, many multifamily dwellings (e.g., condominiums) are often found on or near an amenity, such as a beach, ski resort, or a thriving urban node. Logically, single-family properties proximate to these same amenities will also be proximate to the multifamily residences; capitalizing on the same amenity will bring up the national average substantially. This logic follows the basic principle of Alonso's classic Bid Rent Theory, based on the von Thunen model of land use, stating that as distance increases from a central node, so do transportation costs/time, and therefore rents will decrease (Alonso 1960). Thus, a local amenity may act as a central point for housing price premiums, trumping, at the aggregate level, any nuisance imposed by multifamily dwellings.

Either way, the fact remains that community residents across the nation regularly protest new multifamily housing developments proposed for their neighborhoods (Babcock 1966, Scott 1969, Plotkin 1987, Pendall 1999). An investigation of 182 proposed housing developments in the San Francisco Bay Area during the late 1980s showed that multifamily projects were most likely to encounter NIMBY resistance. In the San Francisco Bay Area study, Pendall found $61 \%$ of all projects prompted some form of public opposition, but multifamily projects were $42 \%$ more likely to generate public controversy than other proposed developments (Pendall 1999).

Even though studies examining the effects of subsidized housing on surrounding property values generally show no monetary effect on surrounding property values (Haughey 2005, Nguyen 2005, Pollakowski 2005), one likely issue with multifamily housing in the US is that it can be associated with more "affordable" housing, attracting lower income and ethnic minority residents. Despite continuous and significant improvements in racial attitudes amongst US Whites, race still partly explains today's housing segregation (Charles 2005, Ihlanfeldt and Scafidi 2004). When Ihlanfeldt and Scafidi (2004) interviewed housing consumers in Atlanta, Boston, Los Angeles, and Detroit to investigate neighborhood racial composition and the willingness to live in a neighborhood, they found that more Black residents meant fewer Whites were willing to live in that neighborhood. In 2000, Pendall conducted an analysis of survey data collected in 1994 for 1,510 localities (including counties, cities, and towns) in the largest 25 metro areas in the United States to investigate low density zoning and racial exclusion. He found a positive correlation. So, while the exclusionary measures may be indirect, they are effective (Pendall 2000).

To further confirm the trend in housing values, Pollakowski (2005) looked at seven multifamily housing developments in suburban Boston that contained at least $20 \%$ subsidized units and were built between 1986 and 2002, following the developments over time and examining surrounding property values to control communities and found no significant differences in property values between study areas and control areas. In another study by the Family Housing Fund in Minnesota, subsidized rental housing did not affect surrounding housing prices (Haughey 2005). In a related study in the San Francisco Bay Area that analyzed the effects of six new multifamily subsidized housing developments on near-by housing units, again no significant adverse effects on nearby housing units were found. In fact, in the San Francisco Bay Area study, some neighboring house values increased as the property was closer to the development (Cummings and Landis 1993).

Whatever the reasons, single-family NIMBY activism against multifamily housing has a very 
real and direct conflict with Smart Growth. The Smart Growth Network (2006) suggests that: "[g]rowth is smart when it gives us great communities, with more choices and personal freedom, good return on public investment, greater opportunity across the community, a thriving natural environment, and a legacy we can be proud to leave our children and grandchildren" (Smart Growth Network 2006, p. 4). Smart Growth directly calls for both density and mixed land uses. The underlying principles of Smart Growth advocate providing a range of housing opportunities and choices: walkable neighborhoods; a mixture of land-uses; preservation of open space, farmland, and natural, beautiful, and environmentally critical areas; a variety of transportation choices (like public transit); and compact building design. Each of these principles requires densities other than single-use, detached, single-family suburban style housing (Smart Growth Network 2006).

While lower density, outward expanding development can have certain quality of life benefits, such as access to environmental amenities and larger houses, it can also cost communities financially via infrastructure and service costs and socially via resident fragmentation and longer commute times (Burchell et al. 2005). Even in communities with growth management regulations like urban growth boundaries to help reduce sprawl (Anthony 2004), such land use regulations may actually increase housing costs if housing options at multiple densities are not available (Ihlanfeldt 2007, Nelson et al. 2002).

Accordingly, Smart Growth promotes dense infill development with a mixture of land uses. Consequently, NIMBY activism against multifamily dwellings directly conflicts with Smart Growth, making Smart Growth principles politically difficult to implement in many communities (Downs 2005, Knaap and Frece 2007). Vocal NIMBY opposition to proposed multifamily housing infill developments can result in project denial (Pendall 1999), which may cause a lack of affordable housing, exclusionary communities, regional economic spatial mismatch between a region's jobs and workforce, and limited access to certain coveted public goods and services like highly valued school systems.

Concerns about property values are understandable, particularly in today's post mid-to-late 2000s housing crash era (Daivs 2010, Li 2011). Property is an investment, and people will naturally want to protect their investments. This is logical. However, unfounded individual concerns that create real costs to society must be addressed and removed from popular discourse as we move forward.

\section{Materials and Methods}

Despite the push for density from anti-sprawl coalitions and Smart Growth advocates, as well as the lack of evidence that multifamily housing developments have negative effects on surrounding single-family property values, NIMBY thinking and action is common in the United States. The result of opposition to proposed multifamily housing developments can lead to a lack of affordable housing and exclusionary communities, regional economic spatial mismatch between a region's jobs and workforce, and general barriers to geographies of opportunities like high quality school systems (Ihlanfeldt 2007, Briggs 2005).

This study assesses multifamily housing intrinsically and by typology: duplexes (two attached units), triplexes (three attached units), quads (four attached units), townhouses (five or more units of row housing), condominiums (five or more units of stacked housing), and apartments (five or more units of stacked rental housing with a single owner). We examined the association with single-family housing prices. Apartments are rental only, but other housing typologies 
(including single-family) may be rentals or owner occupied.

Our central research question asked:

Is there a correlation between proximate types of multifamily dwellings and singlefamily housing prices, and if so, what are the directions and magnitudes of these associations?

The central hypothesis tested was that:

Proximate multifamily dwellings do have a significant negative correlation with singlefamily housing prices, and the more intense the multifamily housing type, the greater the negative association.

For this study, the unit of analysis was the detached single-family property, a parcel of land containing only one residential unit. The study population was a sample of all owner-occupied, primary residences, detached single-family housing units; we used arms-length property transactions recorded in Tallahassee-Leon County, FL, during the calendar year of 2008. All transactions were recorded by the local county property appraiser's office and warehoused with the Florida Department of Revenue. All data in the sample were derived from the Florida Department of Revenue Final Real Property Tax Rolls and accompanying Geographic Informational System (GIS) files (Florida Department of Revenue 2008). Tallahassee is the state capital of Florida; US Census population estimates from July 1, 2008, indicate Tallahassee-Leon County housed 264,063 persons with 159,012 persons actually residing in the City of Tallahassee. This equals 69,173 single-family houses, with a total of 2,027 qualifying transactions for the study sample (United States Census Bureau 2008).

Because we were particularly interested in any monetary association between single-family property and nearby multifamily development, we used a cross-sectional multivariate regression (aka a "hedonic price model") to analyze the data. Hedonic price models assume that price is a function of an item's own features, plus all other associated attributes (Sirmans et al. 2005). In this case, we assumed that the selling price of a property is the sum of its own physical characteristics, its location, and any surrounding [external] characteristics.

The dependent variable in this study was the dollar amount of qualified arms-length transactions for owner-occupied, primary single-family detached residential property in Tallahassee-Leon County. Of a total 2,027 qualified observations, the average selling price was $\$ 193,918.70$, with the standard deviation from the mean being $\$ 76,228.41$ and a range of $\$ 35,000$ to $\$ 400,000$. ${ }^{1)}$ The month of the transaction was included in the model to control for seasonality of housing transactions, which spike during the summer months. The month of transaction was a dummy variable, based on the month of recorded transaction.

The internal property characteristics included in the model for control were the size of the unit's living space, the age of the residential structure, and the lot size. While a wide range of very specific housing characteristics might be considered in an individual's purchasing decision,

1) Sample range chosen to exclude housing transactions recorded as uncharacteristically high or low for the sample population. This meant dropping 149 homes that sold for more than $\$ 400,000$, essentially all homes outside the upper quartile because homes in the upper echelon of the market will skew results, thus not giving the clearest picture of "typical" housing costs in the area. 
these variables control for most differences in single-family housing stock. For example, the age of the house will proxy for features of architectural trends, and the total living space in the house will control for the likely number of bedrooms, and so forth. The external property variables included in the model for control were the property's distance from downtown, which is a proxy for commute times and other locational attributes; the taxing authority, a proxy for taxes levied versus the services rendered; and the Census Block Group, a proxy for fixed neighborhood characteristics.

The independent variable of particular interest was the proximity of single-family house to multifamily housing. Through experimentation with various buffers around multifamily properties, the most logical breaks were 45.72 meters (150 feet) and 91.44 meters (300 feet). The 45.72 meter (150 foot) buffer was optimal for selecting single-family properties directly adjacent to multifamily properties; this buffer distance will hereafter be called "adjacent." The 91.44 meter (300 foot) buffer included single-family properties close but not directly adjacent to multifamily properties; this buffer distance will hereafter be called "nearby." The National Association of Home Builders (2004) study also used a 91.44 meter (300 foot) buffer in their analysis. A larger buffer included too many of the county's total recently sold single-family properties. A visual inspection determined which multifamily property types would be included as buffer originators. Within the nearby buffer, 105 houses were proximate to duplexes, 23 to triplexes, 47 to quads, 148 to townhouses, 15 to condominiums, and 110 to apartments. Within the adjacent buffer, 62 houses were proximate to duplexes, 8 to triplexes, 30 to quads, 77 to townhouses, 6 to condominiums, and 57 to apartments.

Our applied regression models were as follows:

$$
\begin{aligned}
\text { [1] selling price }= & \left.\left.\mathrm{B}_{0}+\mathrm{B}_{1} \text { (proximity to multifamily }\right)+\mathrm{B}_{2} \text { (living space }\right)+\mathrm{B}_{3}(\text { lot size })+\mathrm{B}_{4} \\
& \text { (age of house })+\mathrm{B}_{5}(\text { distance from downtown })+\mathrm{B}_{6}(\text { census block } \\
& \text { group })+\mathrm{B}_{7}(\text { tax authority code })+\mathrm{B}_{8}(\text { month of transaction })+\mathrm{e} \\
\text { [2] selling price }= & \left.\mathrm{B}_{0}+\mathrm{B}_{1}(\text { proximity to duplex })+\mathrm{B}_{2} \text { (proximity to triplex }\right)+\mathrm{B}_{3}(\text { proximity } \\
& \text { to quad }+\mathrm{B}_{4}(\text { proximity to townhouse })+\mathrm{B}_{5}(\text { proximity to } \\
& \text { condominium } \left.)+\mathrm{B}_{6} \text { (proximity to apartments }\right)+\mathrm{B}_{7}(\text { living space })+\mathrm{B}_{8} \\
& (\text { lot size })+\mathrm{B}_{9}(\text { age of house })+\mathrm{B}_{10}(\text { distance from downtown })+\mathrm{B}_{11} \\
& \text { (census block group })+\mathrm{B}_{12}(\text { tax authority code })+\mathrm{B}_{13}(\text { month of } \\
& \text { transaction })+\mathrm{e}
\end{aligned}
$$

When checking for violations to the assumptions of Ordinary Least Squares (OLS), variance inflation factor (vif) was used to test for multicollinearity. All variable scores were less than 4.0 and therefore acceptable. To test for spatial autocorrelation, a Moran's I (index of spatial autocorrelation) was used, and the test indicated a fairly random distribution within the sample (Mitchell 1999). A Breusch-Pagan/Cooks-Weisberg test for heteroskedasticity indicated a lack of constant variance, however, so robust standard errors was applied to down-weight influential observations in the regression (Chatterjee and Hadi 2006, Hoffman 2004). Visual diagnostics indicated that the sample displayed a positively skewed histogram of selling price. However, the central limit theorem states that for larger samples, the distributions of the averages will approach normal regardless of the sample's distribution shape, so this was not a concern (Agresti and Finlay 1997). No other issues were identified during diagnostics.

Table 1 lists and briefly describes all study variables and data sources. Table 2 displays the descriptive statistics. 
Descriptions of Variables

Table 1

\begin{tabular}{|l|l|}
\hline \multicolumn{1}{|c|}{ Variable } & \multicolumn{1}{c|}{ Description } \\
\hline Selling price & $\begin{array}{l}\text { US dollar amount, arms-length real estate transaction, owner- } \\
\text { occupied, primary single-family detached residential property }\end{array}$ \\
\hline Proximity to multifamily & $\begin{array}{l}\text { distance in meters/feet from parcel to multifamily unit housing } \\
\text { (buffer) }\end{array}$ \\
\hline Living space & $\begin{array}{l}\text { total (adjusted) square meters of living space (computed in } \\
\text { square feet) }\end{array}$ \\
\hline Lot size & total hectares (computed in acres) \\
\hline Age of house & 2008 minus year house originally built \\
\hline $\begin{array}{l}\text { Distance from } \\
\text { downtown }\end{array}$ & $\begin{array}{l}\text { distance in kilometers from parcel to center point in downtown } \\
\text { (computed in miles) }\end{array}$ \\
\hline Census Block Group & geographic identification number \\
\hline Tax authority & whether the parcel is in the city or the unincorporated county \\
\hline Month of transaction & month of recorded real estate transaction \\
\hline
\end{tabular}

Descriptive Statistics

Table 2

\begin{tabular}{|c|c|c|}
\hline Variable & Range & $\begin{array}{c}\text { Mean/Standard Deviation or } \\
\text { Percent/Frequency }\end{array}$ \\
\hline Selling price & $\$ 35,000 ; 400,000$ & $\begin{array}{r}\$ 193,918.70 \\
\$ 73,962.06\end{array}$ \\
\hline $\begin{array}{l}\text { [If] adjacent to multifamily } \\
\text { (45.72 meters/150 feet) }\end{array}$ & $0 ; 1$ & $\begin{array}{r}8.58 \% \\
174\end{array}$ \\
\hline $\begin{array}{l}\text { [If] nearby multifamily } \\
\text { (91.44 meters/300 feet) }\end{array}$ & $0 ; 1$ & $\begin{array}{r}13.62 \% \\
276\end{array}$ \\
\hline Living space & $\begin{array}{r}195.07 \text { sqm (640sqft); } \\
1,725.17 \mathrm{sqm} \\
(5,660 \mathrm{sqft})\end{array}$ & $\begin{array}{l}541.16 \mathrm{sqm}(1,775.46 \mathrm{sqft}) \\
183.07 \mathrm{sqm} \text { (600.64sqft) }\end{array}$ \\
\hline Lot size & $\begin{array}{l}.04 \mathrm{~h}(.09 \mathrm{ac}) \\
.98 \mathrm{~h}(2.43 \mathrm{ac})\end{array}$ & $\begin{array}{l}.2 \mathrm{~h}(.50 \mathrm{ac}) \\
.08 \mathrm{~h}(.20 \mathrm{ac})\end{array}$ \\
\hline Age of house & $0 ; 83$ & $\begin{array}{l}17.49 \\
13.41\end{array}$ \\
\hline Distance from downtown & $\begin{array}{r}0.51 \mathrm{k}(.32 \mathrm{mi}) \\
41.88 \mathrm{k}(26.02 \mathrm{mi})\end{array}$ & $\begin{array}{r}8.29 \mathrm{k}(5.15 \mathrm{mi}) \\
4.6 \mathrm{k}(2.86 \mathrm{mi})\end{array}$ \\
\hline In city & $0 ; 1$ & $\begin{array}{r}66.65 \% \\
1,351\end{array}$ \\
\hline
\end{tabular}

Notes: $n=2,027$; sqm $=$ square meters; sqft $=$ square feet; $\mathrm{h}=$ hectares; $\mathrm{ac}=$ acres; $\mathrm{k}=$ kilometers $\mathrm{mi}=$ miles; Census Block Group and month of transaction also regressed, as Stata generated categorical dummy variables for control purposes; distance from downtown remained in its linear form for regression.

\section{Results and Discussion}

Of the 2,027 single-family properties in the sample, 276 or approximately $14 \%$ were nearby 
(within 91.44 meters/300 feet) of one of the six types of multifamily housing, and 174 or approximately $9 \%$ were adjacent (within 45.72 meters/150 feet). Overall, single-family properties selling within these buffers sold for more than the typical single-family properties in the 2008 Tallahassee-Leon County stock. Single-family properties adjacent to multifamily housing sold for $\$ 7,206.68$ more on average, and single-family properties near multifamily housing sold for $\$ 8,244.91$ more on average. In addition to being positive, these coefficients were significant at alpha level .01. This correlation holds with all else being equal in the model: living space, lot size, age of house, distance from downtown, and whether the property was within the city limits. Of the control variables, all but the distance from downtown variable demonstrated statistical significance.

Of the multifamily housing, however, only townhouses and apartments had statistically significant relationships at the individual typology level. Single-family properties adjacent to townhouses sold for $\$ 5,679.47$ more on average, and single-family properties near townhouses sold for $\$ 6,330.26$ more on average. These coefficients were significant at alpha level .05 . Single-family properties adjacent to apartments sold for $\$ 13,427.87$ more on average, and single-family properties near townhouses sold for $\$ 9,372.91$ more on average. These coefficients were significant at alpha level .01 for adjacent housing, and .10 for nearby housing. Please see Table 3 for all regression outputs.

After the initial adjacent and nearby buffer tests, further visual inspection was conducted; any single-family properties in the sample within the designated buffer areas judged not to be reasonably affected by the presence of proximate multifamily housing were noted. This could be because of design, such as the presence of a natural barrier like a dense area of vegetation between the single-family and multifamily housing. A dummy variable was used to indicate single-family housing judged potentially affected by multifamily units versus single-family housing with no visual effect from multifamily units (regardless of proximity). The regressions were then run again, but no combination resulted in any substantial changes to our initial results.

Finally, even though robust standard errors were figured to down-weight any possible influence of observation in all the regressions, the regression was run yet again without any data outside of the respective interquartile range. This time, the observations dropped included nine houses more than 60 years old, eighteen houses with more than 1066.8 square meters $(3,500$ square feet) of living space, and seventy-four houses on more than .36 hectors (nine tenths of an acre). Again, however, no noteworthy changes in the findings were derived from these revisions.

One aspect not captured by this model was the price structure for multifamily dwellings. Changing demographics, specifically characteristics like age, affect the escalating demand for multifamily dwellings, especially in areas conveniently located to various urban design amenities, such as walkable mixed-use neighborhoods (Nelson 2012). While proxies were included to control for fixed metropolitan locational and neighborhood characteristics, the cumulative finding of increased value of single-family housing proximate to multifamily housing may be, in part, a response to capturing the benefits of a transition zone.' To better understand how this phenomenon might influence overall single-family house selling prices in today's cities, further research is warranted. In fact, the findings from our analysis generate new questions for future study. 
Regression Outputs

\begin{tabular}{|l|r|r|}
\hline \multicolumn{1}{|c|}{ Variable } & Adjacent & \multicolumn{1}{|c|}{ Nearby } \\
\hline Proximate to multifamily & $7,206.68^{* * *}$ & $8,244.91^{* * *}$ \\
& $(2,106.20)$ & $(2,550.87)$ \\
\hline Proximate to duplex & $-1,570.54$ & $5,643.85$ \\
& $(3,419.84)$ & $(4,261.71)$ \\
\hline Proximate to triplex & $2,588.259$ & $3,721.067$ \\
& $(9,770.96)$ & $(14,280.05)$ \\
\hline Proximate to quad & $-6,336.50$ & -389.07 \\
& $(5,313.03)$ & $(6,350.41)$ \\
\hline Proximate to townhouse & $5,679.47^{* *}$ & $6,330.26^{* *}$ \\
& $(2,528.45)$ & $(3,185.32)$ \\
\hline Proximate to condominiums & $9,338.09$ & $8,900.07$ \\
& $(10,735.20)$ & $(23,998.22)$ \\
\hline Proximate to apartments & $13,427.87^{* * * *}$ & $9,372.91^{*}$ \\
& $(3,725.02)$ & $(4,972.92)$ \\
\hline Living space & $88.89^{* * * *}$ & $89.23^{* * * *}$ \\
& $(2.810)$ & $(2.81)$ \\
\hline Lot size & $7,105.70^{*}$ & $7,220.14^{*}$ \\
& $(3,707.20)$ & $(3,746.29)$ \\
\hline Age of house & $-872.54^{* * * *}$ & $-868.69^{* * *}$ \\
& $(73.33)$ & $(74.370)$ \\
\hline Distance from downtown & .28 & .29 \\
& $(.27)$ & $(.28)$ \\
\hline In city & $8,686.89^{* * *}$ & $(2938.57)$ \\
\hline Adjusted R-square & $(2,929.18)$ & 0.8795 \\
(Prob $>$ F = 0.0000) & 0.8803 & \\
\hline
\end{tabular}

Notes: coefficients (robust standard errors); $n=2,027$; ${ }^{*}<<.10$; ${ }^{* *} \mathrm{P}<.05 ;{ }^{* * *} \mathrm{P}<.01$; ${ }^{* \star * *} \mathrm{P}<.001$; negative coefficients noted by "-"; Living space computed in feet, Lot size computed in acres, Distance from downtown computed in miles

\section{Conclusions}

We found no statistically significant negative associations between multifamily housing and single-family property selling price in this study. In fact, we found the opposite both overall and individually for the typologies of townhouses and apartments. A townhouse is perhaps the most non-intrusive form of multifamily housing, and it was not uncommon to find this type of development in upscale Tallahassee neighborhoods, so finding this type of multifamily dwelling positively correlated with single-family property price was a rather bland finding. Apartments, on the other hand, were potentially the most perceivably intrusive of the six multifamily typologies, and the positive finding for this typology perhaps warrants further consideration.

One logical explanation for this positive association was that high density apartments were, by zoning and design, in mostly dense urban settings, close to urban amenities, thereby making the land valuable and thus prime for multifamily development. Thus, logically, the proximate single-family property will capitalize on the same urban amenity and therefore the monetary land value for the area. This is consistent with the explanation offered in the National 
Association of Home Builder's (2004) study. Future study on community amenity could verify this hypothesis, but the speculation is certainly reasonable.

Another aspect to consider in future study is the price structure of the multifamily dwellings. As US Baby Boomers downsize, seeking homes with less maintenance, in neighborhoods with more walkable amenities and as Gen $Y$ begins to reject the normative concept of suburban homeownership as the "American Dream" in an effort to be more flexible and resilient in their lives (Nelson 2012), we must examine the future of our cities, not just housing options and markets, but overall urban form. Yesterday's middle-class, single-family, home owning suburbanite NIMBY may very well be tomorrow's multifamily urban dweller. This will change the traditional perception of residents. As population dynamics change, so do wants, needs, markets, perceptions, and politics. As with most social science research, studies often raise more questions than they provide answers. This study is no exception and this is actually a positive outcome. As a result, we begin to ponder bigger questions upon drawing our conclusions. We wonder, for example, how the findings in this study relate to shifts in tomorrow's urban planning and design, and how the politics of Smart Growth will change. Is the single-family house tomorrow's "nuisance" on functional society? We can, of course, only speculate, but we do know that urban planners have been attempting to combat the costs of suburban sprawl for decades (Burchell et al. 2005), and the Smart Growth agenda is at the forefront of that effort (Smart Growth Network 2006).

Finding no statistically significant negative correlation between the selling prices of proximate multifamily housing and single-family property was fully in line with all previous studies reviewed, providing further evidence that directly contradicts commonly stated NIMBY concerns of monetary devaluation to surrounding single-family property when multifamily housing is close. If a single-family housing consumer simply prefers not to live near dense housing populations or large structures for personal and/or aesthetic reasons, this study cannot argue with that preference. However, the monetary argument stating that multifamily housing is a negative influence on single-family property value was not substantiated by this study. In fact, monetarily speaking, multifamily development proximate to single-family property is more likely to be positively associated with single-family property selling prices. Thus, single-family homeowners should perhaps rejoice when new multifamily neighbors arrive.

Nonetheless, the authors hope that these results will both help alleviate the concerns of singlefamily homeowners, monetarily speaking, and help local governments feel more comfortable creating and implementing policies that are more conducive to Smart Growth.

\section{References}

AGRESTI, A., FINLAY, B. (1997), Statistical Methods for the Social Sciences, Third Edition, Upper Saddle River, NJ: Prentice Hall.

ALONSO, W. (1960), A Theory of the Urban Land Markets, Papers and Proceedings of the Regional Science Association, 6, pp. 149-157.

ANTHONY, J. (2004), Do State Growth Management Regulations Reduce Sprawl, Urban Affairs Review, 39, 3, pp. 376-397.

BABCOCK, R., F. (1966), The zoning game: Municipal practices and policies, University of Wisconsin Press, Madison.

BRIGGS, X., editor (2005), The Geography of Opportunity: Race and Housing Choice in

Metropolitan Community, Brookings Institution Press, Washington DC.

BURCHELL, R., W., DOWNS, A., MCCANN, B., MUKHERJI, S. (2005), Sprawl Costs: 
Economic Impacts of Unchecked Development, Island Press, Washington DC.

CUMMINGS, P., LANDIS, J. (1993), Relationships between affordable housing developments and neighboring property values: An analysis of BRIDGE Housing Corporation developments in the San Francisco Bay Area, Working paper 599, Institute of Urban and Regional Planning, UC Berkley.

CHARLES, C. (2005), Can We Live Together? Racial Preferences and Neighborhood Outcomes. In The Geography of Opportunity: Race and Housing Choice in Metropolitan Community, edited by X. Briggs, Brookings Institution Press, Washington DC.

CHATTERJEE, S., HADI, A., S. (2006), Regression Analysis by Example, Hoboken, NJ: John Wiley and Sons, Inc.

DAIVS, M., A. (2010), Reflections on the foreclosure crisis, Land Lines, July, pp. 1-8.

DOWNS, A. (2005), Smart Growth: Why We Discuss It More than We Do It, Journal of the American Planning Association, 71, 4, pp. 367-378.

FISCHEL, W. (2000), The Homevoter Hypothesis, Harvard University Press, Cambridge, Massachusetts.

FLORIDA DEPARTMENT OF REVENUE (2008), Final Real Property, Tax Rolls,

Tallahassee, Florida.

HAUGHEY, R., M. (2005), Higher Density Housing: Myths and Facts, The Urban Land Institute, Washington DC.

HOFFMAN, J., P. (2004), Generalized Linear Models: An Applied Approach, MA: Pearson Education Inc., Boston.

IHLANFELDT, K. (2007), The Effect of Land Use Regulation on Housing and Land

Prices, Journal of Urban Economics, 61, 3, pp. 420-35.

IHLANFELDT, K., SCAFIDI, B. (2004), Whites' neighbourhood racial preferences and neighbourhood racial composition in the United States: evidence from the multi-city study of urban inequality, Housing Studies, 19, 3, pp. 325-359.

KNAAP, G., J., FRECE, J.,W. (2007), Smart Growth in Maryland: Looking Forward and Back, Idaho Law Review, 43, pp. 1-30.

LI, Y. (2011), Geography of Opportunity and Residential Mortgage Foreclosure: A Spatial Analysis of a U.S. Housing Market, Journal of Urban and Regional Analysis, 3, 2, pp. 195-214. California.

MITCHELL, A. (1999), The ESRI guide to GIS analysis, ESRI Press, Redlands,

NELSON, A., C. (2012), Reshaping Metropolitan America: Trends and Opportunities to 2030, Island Press, Washington, DC.

NELSON, A., C., PENDALL, R., DAWKINS, C., J., KNAPP, G. J. (2002), The Link

Between Growth Management and Housing Affordability: The Academic Evidence, Brookings

Report, Brookings Institution Press, Washington DC.

NGUYEN, M., T. (2005), Does Affordable Housing Detrimentally Affect Property

Values? A Review of the Literature, Journal of Planning Literature, 20, 1, pp. 15-26.

PENDALL, R. (1999), Opposition to Housing: NIMBY and Beyond, Urban Affairs

Review, 35, 1, pp. 112-136.

PENDALL, R. (2000), Local land use regulation and the chain of exclusion, Journal of the American Planning Association, 66, pp. 125-142.

PLOTKIN, S. (1987), Keep out: The struggle for land use control, Univserity of Califorinia Press, Berkeley.

POLLAKOWSKI, H. (2005), Effects of Mixed-Income Multifamily Rental Housing Developements on Single Family Housing Values, MIT Center for Real Estate, Cambridge. Berkeley. SCOTT, M. (1969), American city planning since 1890, University of California Press,

SIRMANS, G., D., MACPHERSON, D., ZIETZ, E., N. (2005), The Composition of 
Smart Growth and the Challenge of Nimby: Multifamily Dwellings and their Association with Single-Family House Selling Prices in Tallahassee, Florida, USA

Hedonic Pricing Models, Journal of Real Estate Literature, 12, 1, pp. 3-43.

SMART GROWTH NETWORK (2006), This is Smart Growth, Retrieved from: http:/l www.smartgrowthonlineaudio.org/pdf/TISG_2006_8-5x11.pdf.

TIEBOUT, C. (1956), A Pure Theory of Local Expenditures, Journal of Political Economy, 64, pp. 416-424.

UNITED STATES CENSUS BUREAU (2009), Population Estimates, Information retrieved from the web December 2009, http://quickfacts.census.gov/qfd/states/12/12073.html \& http://quickfacts.census.gov/qfd/states/12/1270600.html.

UNITED STATES DEPARTMENT OF HOUSING AND URBAN DEVELOPMENT (1995), Homeownership and Its Benefits, Office of Policy Development and Research, Urban Policy Brief, 2(August), Washington DC.

UNITED STATES NATIONAL ASSOCIATION OF HOME BUILDERS (2004), Market Outlook: Confronting the Myths about Apartments with Facts, Washington DC.

Initial submission: .29.01.2013

Revised submission: 03.05.2013

Final acceptance: 31.05.2013

Correspondence: Huston J. Gibson, Landscape Architecture/Regional and Community Planning, The College of Architecture, Planning \& Design, Kansas State University, 302 Seaton, Manhattan, KS 66506-2902

E-mail: hgibson@k-state.edu 
